\title{
Descriptions of new species belonging to the sub-family PIMPLARI E found in America north of Mexico.
}

\author{
BY E. T. CRESSON.
}

ACENITES, Grav.

Acœnites rupinsulensis, Walsh, MS. - + .-Entirely pale honey-yellow, polished ; antennæ blackish at base above, short, with thick set joints ; tip of mandibles and vertex black; legs short, posterior femora swollen; wings hyaline. Length 4 lines.

Mab.-Illinois. Sent me by Mr. Walsh named as above, along with other Ichneumonidæ with MS. names attached. Now that he is gone, I hesitate no longer to describe them, always adopting his names when not pre-occupied, and recognizing him as the discoverer of the species.

EPHIAITES, Grav.

Ephialtes perlongus, n. sp.- $\hat{\jmath}$.-Head and thorax black, polished; antennæ black; palpi white; abdomen very long, slender, cylindrical, piceous-black, pale at base of segments, alutaceous, first segment elongate, bicarinate, deeply excavate at base, the following segments at least twice longer than broad, segments 2 and 3 with a lateral deeply impressed line; face with a dense pale sericeous pile; legs honey-yellow, tips of posterior femora and their tibiæ and tarsi entirely, fuscous, sericeous; wings hyaline, beautifully iridescent. Length $5 \frac{1}{2}$ lines.

Hab.-Massachusetts.

Ephialtes albipes, n. sp.- + .-Long, slender, black, opaque, pale sericeous in certain lights; palpi, scape beneath, tegulæ and four anterior coxæ and legs, white; posterior coxæ and femora honey-yellow, their trochanters white, with a black spot above, their tibiæ and tarsi fuscous, the former whitish at base; wings hyaline, beautifully iridescent; abdomen sub-cylindrical, surface smooth, without any elevations or depressions, the second and following segments about twice longer than broad; ovipositor shorter than abdomen, the sheaths scarcely pubescent. Length $4 \frac{1}{2}$ lines.

Hab.-New Jersey.

EPIMECIS, Brullé.

E. Wiltii, n. sp.- + .-Pale honey-yellow, polished; head, except month, and palpi black; antennæ nearly as long as the body, brown-black; wings yellow-hyaline, iridescent, with a fuliginous band across the middle, emarginate outwardly, and a broad one at tip, nervures and stigma yellow except within the fuliginous band; tips of tarsi dusky; four apical segments of abdomen dusky (probably discolored); ovipositor exserted half the length of abdomen, ferruginous, valves black. Length 7 lines.

Hab.-Ohio. Closely ailied to fascipennis, Cresson, from Cuba, which is smaller, and has the outer margin of the median fuliginous band on anterior wing perfectly straight and not emarginate as in Wiltii, and the posterior tibiæ and tarsi are entirely fuscous.

Dedicated to Mr. Charles Wilt, to whom the Society is indebted for the unique in its collection. 
PIMPLA, Fabr.

The species of this genus, as far as known to me, may be distinguished by the characters given in the following table.

Body black.

Legs black, anterior pair pale in front; scutellum white.....1. maura, n. sp.

Legs yellowish-red, posterior pair variei with black and white.

Coxæ black....

2. atrocoxalis, n. sp.

Coxæ yellowish-red.

Posterior tibiæ and tarsi entirely black or fuscous.

Wings hyaline; abdomen sparsely punctured.

3. pedalis, Cress.

Wings fuliginous; abdomen finely granulated.

4. texana, n. sp.

Posterior tibiæ black, annulated with white.

Posterior tarsi entirely black or fuscous.

Scutellum black, tegulæ and anterior coxæ black..5. tenuicornis, Cress.

Scutellum black, tegulæ white, anterior coxæ yellowish-red

6. annulipes, Brullé.

Scutellum white 7. aquilonia, n. sp.

Posterior tarsi with basal half of first joint only, white.

Posterior tibiæ black, with a white annulus near base.

Antennæ black above, fuscous beneath; mesothorax entirely black; tip only of scutellum white...

8. Ontario, n. sp.

Antennæ fuscous above, pale luteous beneath with black incisures ; mesothorax with two short discal white lines; scutellum white....

9. picticornis, n. sp.

Posterior tibiæ with narrow annulus at base and stripe beneath, reaching to apical third, white....

10. novita. n. sp.

Posterior tarsi with two basal joints white tipped with black, scape white; size small, slender............11. indagatrix, Walsh.

Posterior tarsi white, the joints tipped with black.

Antennæ pale luteous, incisures black........12. annulicornis, Walsh.

Antennæ unicolorous, brown or ferruginous.

Abdominal segments with narrow white apical margins...

13. conquisitor, Say.

Abdominal segments entirely black.

Areolet of anterior wing incomplete....

14. incompleta, n. sp.

Areolet of anterior wing complete.

Head entirely black ( $q)$, face white

$(\widehat{\delta})$; tegulæ white.

15. inquisitor, Say.

Clypeus only, scape beneath, tegulæ and most of four anterior legs white $(\delta)$ 16. alboricta, n. sp.

Clypeus, more or less, anterior orbits, tegulæ, line before, and tip of scutellums, white; pleura more or less red.

Pleura almost entirely red; two dots below insertion of antennæ, clypeus entirely and dot on each side of metathorax behind, white.

17. rufopectus, n. sp.

Pleura red only before middle coxæ; tip of clypeus more or less blackish; no white dots below insertion of antennæ; metathorax immaculate... 18. scriptifrons, Walsh, 
Legs entirely red or yellowish-red, sometimes obfuscated.

Thorax entirely black, smooth and polished....

19. pterelas, Say.

Mesothorax at sides, scutellum and pleura, sanguineous...20. notanda, n. sp. Body black, most of abdomen and legs sanguineous........21. rufovariata, n. sp.

1. Pimpla maura, n. sp.- $q .-$ Black, supopaque; dot on tip of scape beneath, spot on scutellum, sub-obsolete line on postscutellum, and anterior legs in front, whitish; wings dark fuscous, nervures and stigma black, the latter pale at base; antennæ brown-black. Form robust; head and thorax rather finely punctured, face rugosely so; metathorax transversely rugose; abdomen robust, segments short and transverse, densely and coarsely punctured, extreme apical margins smooth; excavated base of first segment smooth and polished; ovipositor much shorter than abdomen, robust, sheaths finely pilose. Length 6 lines.

Hab.-Texas. This is our largest and most robust species, and easily distinguished by the color, both of body and legs, being almost entirely black.

2. Pimpla atrocoxalis, n. sp.- $9 .-$ Head, thorax, abdomen, coxæ and trochanters entirely black; rest of legs yellowish-red; wings subhyaline, tinged more strongly with fuliginous toward apex; (antennæ wanting). Form subrobust, very densely punctured, the punctures more coarse on abdomen; posterior femora robust; abdomen subfusiform, seventh segment less densely and coarsely punctured than the others and shining. Length $5 \frac{1}{2}$ lines.

Hab.-Hudson's Bay Territory. Readily known by the reddish legs, with all the coxæ and trochanters black.

4. Pimpla texana, n. sp. - $q .-$ Black, head and thorax shining; clypeus and mandibles dark rufous; a white spot between eye and base of mandible; antennæ brown-black, slender; mesothorax, scutellum and pleura smooth and polished; metathorax sub-truncate behind, with a carina on each side, meeting above and forming a small conical cell on the disk; wings uniformily fuseohyaline, nervure black, stigma brown, areolet rhomboidal; legs, including all the coxæ, rufous, posterior tibiæ and tarsi black; abdomen with upper surface not impressed, finely granulated, with a silky gloss. Length 4 lines.

Hab.-Texas. Very distinct from pedalis by the dark wings and finely granulated abdomen.

7. Pimpla aquilonia, n. sp.- $-\hat{\delta}--$ Black, head and thorax shining; metathorax and abdomen with a short, rather dense, pale sericeous pile; antennæ slender, testaceous, scape fuscous; tegulæ and spot on scutellum, white; metathorax smooth and rounded; wings hyaline, iridescent, stigma and veins brown-black, former pale at base, areolet rhomboidal; legs yellowish-red, anterior coxæ paler, posterior tibiæ black, with a rather broad white annulus, their tarsi blackish, the joints slightly paler at base; abdomen narrow, slightly broader towards apex, opaque, very densely and minutely punctured. Length $3 \frac{1}{2}$ lines.

Hab.-Maine. Differs from tenuicornis by the shape and sculpture of the abdomen, which in the latter species is narrowed towards apex, the segments constricted at base, the surface densely and coarsely punctured, with the apical margin smooth and polished; while in aquilunia the surface is even, entirely punctured and very minutely so. 
8. Pimpla 0nt.rio, n. sp.-- $\} \cdot-$ Black, shining; face, clypeus, mandibles except tips, palpi, spot on seape beneath, tegulæ and apex of scutellum and postscutellum, white; wings hyaline, iridescent, stigma and veins blackish, the former with a white spot at base, areolet small, 5-angular; legs yellowish-red, four anterior $\operatorname{cox} \circledast$ and trochanters beneath white, posterior tibiæ and tarsi blaskish, with a broad annulus on the former and basal half of first joint of the latter, white; metathorax shining, delicately punctured, with a short pale pubescence, apex rounded; abdomen long, narrow, sub-cylindrical, closely and delicately punctured; antennæ long, subrobust, and of uniform thickness throughout. Length 5 lines.

Hab.-Canada.

9. Pimpla picticornis, n. sp.-- .-Black; face (except short longitudinal, elevated black line on middle), clypeus, spot on mandibles, palpi, narrow anterior orbits slightly interrupted before summit, scape beneath,teşulæ, spot beneath, scutellum, postscutellum, two short lines on disk of mesothorax, anterior coxæand trochanters, and four anterior tibiæ and tarsi, white; antennæ long. setaceous, brown above, pale luteous beneath, with incisures black; wings hyaline, iridescent, apex faintly clouded, stigma black, pale at base and apex, areolet moderate, 5-angular; metathorax polished, not abrupt behind; legs pale yellowish-red, posterior tibiæ and tarsi black, a rather narrow annulus near base of former and base of first joint of latter, white; abdomen broader than usual for the sex, very densely and confluently punctured, with a fine pale sericeous pile; lateral swellings transverse. Length $4 \frac{1}{2}$ lines.

Hab.-New Jersey. Quite distinct from all other species by the two short white lines on disc of mesothorax, and black spot on the face.

10. Pimpla novita, n. sp.- $q$.-Elongate, black, shining; large spot on each mandible, palpi and tegulæ, white; metathorax shining, with an oval discal depression, apex truncate; wings hyaline, iridescent, nervures and stigma brown, areolet subtriangular; legs short, rather slender, pale reddish-yellow, four anterior trochanters whitish, posterior tibiæ black, white at base and beneath nearly to apex, their tarsi black, basal half of first joint white; head and thorax smootli and polished; abdomen subfusiform, shining, very minutely sculptured, first segment with an-oblong-ovate depression on disk; sheaths of ovipositor with long, dense pubesence. Length 4 lines.

Hab.-Massachusetts. Easily distinguished by the large white spot on each mandible, and by the ornamentation of posterior tibiæ.

11. Pimpla indagatrix, Walsh, MS.- $\delta$-Black, shining; palpi, scape beneath, tegulæ, four anterior legs and posterior trochanters, white ; four anterior femora slightly tinged with yellow; posterior legs yellowistr-red, their tibiæ white, with apex and narrow annulus near base, black; posterior tarsi black, two basal joints white tipped with black; wings hyaline, iridescent, nervures and stigma fuscous; areolet subrhomboidal; abdomen long, narrow, linear, minutely punctured, subpubescent, sometimes the segments are brownish or piceous at base. Length $2 \frac{1}{2}$ lines.

Hab.-Pennsylvania; Illinois. This is the smallest species so far known to me, and is easily distinguished by the characters given above. 
12. Pimpla annulicornis, Walsh, MS.- +- Black, shining; very narrow anterior orbits, tegulæ and apex of scutellums, white; palpi pale; antennæ pale luteous, with incisures of joints black; wings hyaline, stigma black, whitish at base, areolet small, subtriangular; legs yellowish-red, anterior coxæ black with apices pale; posterior tibiæ black with broad white annulus, three basal joints of their tarsi yellowish, with apices and two apical joints black; metathorax with short pale pubescence, bicarinate on disk; abdomen broad, very closely and deeply punctured, incisures deep, first segment bicarinate above. Length $5 \frac{1}{2}$ lines.

The $\delta$ has white face, clypeus, mandibles, palpi, scape beneath, four anterior coxæ and base of legs beneath; wings beautifully iridescent, areolet minute; three basal joints of posterior tibiæ white tipped with black; abdomen very densely punctured and with short glittering white pile. Length $4 \frac{1}{2}$ lines.

Hab.-Pennsylvania, $\uparrow$; Illinois, $\hat{\delta}$. Differs from picticornis by the immaculate mesothorax, different ornamentation of posterior legs and by the abdomen being more distinctly, less confusedly, punctured. The antennæ of both species are colored much alike.

14. Pimpla incompleta, n. sp.- $q$.-Black, shining; elypeus piceous; palpi whitish; antennæ rufo-testaceous, slender; head and thorax smooth and polished; wings hyaline, iridescent, nervures and stigma pale brown, areolet moderately large, 5 -angular, the outer nervure entirely obliterated ; legs yellowish-red; annulus on middle of intermediate tibiæ and base of tarsal joints, white; posterior tibiæ black, with a broad white annulus about the middle, their tarsal joints pale, tipped with black; abdomen broader than usual, closely punctured, with apical margins of segments smooth; on second and three following segments a transverse depression, deeper laterally and producing a transverse swelling which is more feebly punctured and more shining than the surrounding surface; the apical segments smooth and polished. Length $2 \frac{1}{2}$ lines.

Hab.-Illinois. A very small species, easily distinguished by the incomplete areolet of anterior wings. The shape and sculpture of the abdomen is similar to that of pterelas, Say, but proportionally broader, with the lateral swellings more prominent.

16. Pimpla alboricta, n. sp.- $-\delta .-B l a c k$, shining; clypeus, middle of mandibles, palpi, two basal joints of antennæ beneath, tegulæ, spot before, four anterior coxæ, all the trochanters and four, anterior tibiæ and tarsi, white; posterior coxæ and all the femora yellowish-red; posterior tibiæ white, with spot near base and apical fourth black, as also tips of their femora; their tarsi black, the first, except tip, and base of remaining joints more or less, white; wings hyaline, iridescent, nervures and stigma black, areolet minute, petiolated, obliquely linear; bead and thorax smooth and polished; mesothorax prominently trilobed anteriorly; metathorax with a central longitudinal channel; abdomen long and narrow, more or less tinged with brown, distinetly punctured, apical margins of segments smooth and polished, lateral swellings prominent, first segment with two prominent longitudinal carinæ, apical segment acuminate, smooth and shining. Length $3 \frac{1}{2}-4$ lines.

Hab.-Pennsylvania; Delaware. Readily distinguished from all 
other species by having the entire clypeus, most of mandibles and two basal joints of antennæ beneath, white; and by the minute, almost obsolete, areolet of anterior wings.

17. Pimpla rufopectus, n. sp.- - - - Black, shining; elypeus entirely, spot on mandibles, palpi, anterior orbits-dilated at summit, two dots beneath insertion of antennæ, tegulæ, line before, short line beneath, tip of scutellums, dot on eąch side of metathorax behind, anterior coxæ, four anterior trochanters, tibiæ and tarsi, and venter except lateral black spot on each segment, white; most of pleura, four posterior coxæ, all the femora, and posterior trochanters, yellowish-red; posterior tibiæ and tarsi whitish, spot near base of tibiæ, their apical fourth and tarsal tips, black; scutellum tinged with rufous; antennæ brown, pale at base beneath ; wings hyaline, nervures blackish, base and apex of stigma pale, areolet obliquely subquadrangular; head and thorax shining; abdomen with elose, distinet punctures, apical margin of segments smooth and polished, lateral swellings prominent; first segment short and deeply excavated at base which is smooth and polished; mesothorax prominent anteriorly; metathorax short, rounded above and truncate behind, sides with whitish pubescence; ovipositor short. Length 5 lines.

Hab.-Pennsylvania.

18. Pimpla scriptifrons, Walsh, MS.- $q .-$ Black, shining; elypeus exeept apex, narrow anterior orbits-broader at summit, palpi, tegulæ, line before, transverse spot beneath and tip of scutellums, white; antennæ brown, paler beneath, whitish at base beneath; wings hyaline, iridescent, stigma pale brown, whitish at base, areolet subtriangular, slightly oblique; legs slender, yellowish-red, anterior coxæ, all the trochanters, tips of intermediate femora, and their tibiæ except apex, white; posterior tibiæ white, with the apical fourth and a narrow annulus near base, black; intermediate tarsi white, the joints tipped with black, posterior pair black, with base of the joints white, apex of posterior femora black, edged with wnite; thorax smooth and polished; pleura beneath, before intermediate coxæ, reddish; abdomen shining, closely and confluently punctured, broad apical margin of segments smooth and polished, a median transverse depression on second and following segments, which are constricted at base; antennæ slender. Length 4 lines.

Mab.-Delaware; Illinois. Smaller and more slender than rufopectus, to which it is closely allied.

20. Pimpla notanda, n. sp.- .--Black, shining; paipi, tegulæ and short line before, white: antennæ short, black, apex reddish; a broad line on each side of mesothorax, scutellum, postscutellum, pleura except broad upper margin, and legs entirely, sanguineous; wings hyaline, nervures and stigma brown, areolet subtriangular, slightly oblique; abdomen long, with elose, distinct punctures; ovipositor nearly as long as body ; venter white, with lateral black spots. Length $4-5$ lines.

$\delta$. More slender, face black; metathorax with a red spot on each extreme lateral margin; anterior coxæ and trochanters white; posterior tibiæ and tarsi fuscous, the former with a white stripe behind, and the tarsi white at base of first joint; abdomen sometimes tinged with brown, the lateral swellings more prominent than in $q$. Length $3 \frac{1}{2}-5$ lines.

Mab.-Penn.; New Jer'sey; Colorado. Easily distinguished by the handsome ornamentation of the thorax. 
21. Pimpla rufovariata, n. sp.- + .-Black, shining; palpi and antennæ beneath, pale luteous; the incisures of latter blackish, upper surface brown; tegulæ pale; legs ferruginous, posterior tarsi paler, with tips blackish, tips of tibiæ also blackish ; wings dusky hyaline, nervures and stigma black, areolet subtriangular; abdomen closely and confluently punctured, second, third and most of fourth segments sanguineous, with a short, black, transverse line on each side of apex, lateral swellings prominent; venter more or less sanguineous; head and thorax obsoletely punctured; metathorax rugulose, with prominent longitudinal carinæ; ovipositor one-fourth the length of abdomen. Length 4 lines.

Var. 9.-Abdomen entirely sanguineous except apex, which is obfuscated, and the lateral black lines on apical margin. Length $2 \frac{1}{2}$ lines.

Mab.-Pennsylvania; New Jersey. Quite distinct from all the other known species of this genus.

POLYSPHINCTA, Grav.

The species of this genus have much the appearance of those of Pimpla, but may be at once separated by the absence of the areolet of anterior wing.

Only three species are known to me, which may be arranged as follows :

Abdomen punctured or rugulose.

Posterior tibiæ white, biannulate with black; their tarsi black, white only at base of first joint............ texana, n. sp.

Posterior tibiæ white, black only at apex; their tarsi white, black at tip of all the joints...

2. Burgessii, n. sp. Abdomen polished, impunctured 3. limata, n. sp.

1. Polysphincta texana, n. sp.- $q$.-Black, shining; mouth rufo-piceous; palpi, tegulæand dot before, whitish; wings hýaline, nervures and stigma black, the latter pale at base; legs yellowish-red; apex of anterior coxæ, four anterior trochanters and their tibiæ, anterior tarsi except tips, and base of intermediate tarsi, pale yellowish; intermediate tibiæ with a black spot behind near base, their tarsi except base fuscous; posterior tibiæ white, a narrow band near base, their apical fourth and a stripe within, not reaching their base, black; apex of their femora and their tarsi, except basal half of first joint which is white, also black; antennæ about three-fourths the length of the body, slender; face narrow ; clypeus convex; eyes large, prominent, ovate; head and thorax polished; mesothorax prominently trilobed; scutellum raised, carinate laterally ; metathorax rounded, densely clothed with pale pubescence; legs subrobust; abdomen elongate, rather robust, closely and distinctly punctured, more sparsely so on apical margin of the segments which are prominent, lateral swellings prominent and rounded, segments deeply incised at base, first segment deeply grooved at base, the groove converging to apex; apical segment short, blunt, obsoletely punctured; ovipositor very short; venter whitish, with lateral black spot on each segment. Length 5 lines.

\section{Hab.-Texas.}

2. Polysphincta Burgessii, n. sp.- $-\hat{\delta} \cdot-$ Black, shining; palpi, tip of first and second (entirely) joints of antennæ beneath, tegulæ, dot before, four anterior

SEPTEMBER, 1870 . 
coxæ, all the trochanters, tips of four anterior femora, all the tibiæ (exeept apices of posterior pair which are black), and all their tarsi (except tips of intermediate pair which are pale brown and of posterior pair which are black), pale yellowish-white; wings hyaline, iridescent, nervures and stigma black, the latter large and with a pale dot at base; abdomen densely and minutely rugulose, with apical margins of segments smooth, lateral swellings prominent; first segment deeply grooved at base; scutellum rufo-piceous; metáthorax with a central longitudinal channel; antennæ pale brown. Length 8 lines.

Hab.-Beverly, Mass. This beautiful little species is respectfully dedicated to my friend Mr. Edward Burgess, of Boston, to whom science is indebted for the discovery of many gems in Hymenoptera.

3. Polysphincta limata, n. sp.- $q .-$ Black, polished, impunctured; palpi, tegulæ and dot before, white; mandibles rufo-testaceous; antennæ nearly as long as body, slender, brown; scutellum and postscutellum rufous, the former blackish on disk; wings hyaline, iridescent, nervures and stigma brown; legs slender, yellowish-red; tips of anterior coxæ, all the trochanters, and more or less of four anterior tibiæ, pale yellowish ; four posterior tarsi whitish, with the joints tipped with black; posterior tibiæ as in texana; tips of posterior femora blackish ; metathorax with a rather deep, central, longitudinal channel; abdomen polished, impunctured, finely and sparsely pubescent, lateral swellings prominent, deeply grooved above, the groove couverging to apex; ovipositor scarcely half the length of abdomen. Length 4 lines.

Var. $q .-$ Scutellum and pleura pale rufous; the sub-basal black spot on posterior tibiæ wanting.

Hab.-Massachusetts; New Jersey. Readily distinguished by the polished, impunctured abdomen.

CLISTOPYGA, Grav.

Clistopyga annulipes, n. sp.- $q$.-Black, shining; anterior orbits, extending slightly beyond summit of eyes, a transverse spot beneath insertion of each antenna and confluent with orbital line, clypeus entirely, mandibles except tips, spot beneath each eye, palpi, tegulæ, line before, spot beneath, tip of scutellum, spot on postscutellum, and very narrow apical margin of abdominal segments, white; remainder of scutellum pale rufous; wings hyaline, nervures and stigma piceous; legs pale ferruginous, four anterior coxæ and anterior legs in front, pale yellowish; four posterior tibiæ and tarsi black or blackish, the tibiæ with a narrow, white annulus about the middle, and the tarsal joints more or less white at base ; antennæ long, slender, black above, brown beneath; pleura very finely and sparsely punctured; metathorax convex, with short, fine, pale glittering pubescence laterally, upper surface minutely transversely aciculated; legs short, subrobust, posterior tibiæ scarcely longer than the two basal joints of their tarsi; abdomen long, subrobust, convex, surface even, shining, finely and closely punctured, and with short, fine, erect pubesence; first segment excavated at base; apical segment truncate; ovipositor not half the length of abdomen, sheaths with long pubescence. Length $5 \frac{1}{2}$ lines.

Hab.-Massachusetts. One specimen with the mesothorax almost entirely destroyed. 
GLYPTA, Grav.

This genus is known at once by the more or less deep oblique grooves on each side of the second, third and fourth dorsal segments of the abdomen, and the absence of the areolet of anterior wing; otherwise it closely resembles Pimpla.

The species are numerous and may be distinguished by the characters given in the following table.

Posterior tibiæ and tarsi banded with black and white.

Pleura entirely black.

Posterior tibiæ white, with two entire black bands; clypeus, $q$, black 1. tuberculifrons, Walsh.

Posterior tibiæ white, with two black bands above, and black stripe beneath.

Mandibles black; clypeus dark rufous, piceous or black,

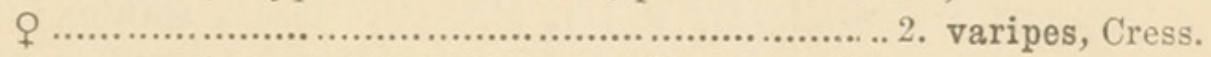

Mandibles, except tips, white; clypeus rufous or yellowish, $\delta$ o …................................................ erratica, n. sp.

Posterior tibiæ white, with two black bands beneath and black stripe above, $q$.......................................................... inversa, n. sp.

Pleura more or less red.

Scutellum entirely black; clypeus and mandibles white; posterior tibiæ white with two entire black bands; pleura with a small red spot on each"side....

5. pulchripes, n. sp.

Scutellum more or less red.

Pleura black, with a longitudinal red mark or spot on each side; clypeus and mandibles rufous. 6. rufiscutellaris, Walsh.

Pleura red only beneath between the four anterior coxæ; upper margin of prothorax white; posterior tibiæ with two entire black bands.... 7. animosa, n. sp.

Pleura, except space beneath wings, red.

Abdomen entirely black.

Posterior tibiæ with two black bands above and black stripe beneath; clypeus and mandibles white...

8. vulgaris, n. sp.

Posterior tibiæ black, white only at base, pale fuscous in the middle; most of face white; form long and slender.9. longiventris, Walsh.

Abdomen black, the three basal segments more or less red at apex

Pleura, mesothorax and scutellum reddish.

Abdomen entirely black or fuscous.

Legs reddish, posterior tibiæ and tarsi black and white; abdomen black 11. monita, n. sp.

Legs white, varied with blackish; abdomen fuscous. 12. parva, n. sp.

Abdomen black with apical margin of each segment and a median dot white, also the face, mouth and orbits

13. scitula, n. sp.

Posterior tibłæ and tarsi ferrugiuous or more or less blackish, not annulated with black and white.

Abdomen entirely black.

Scutellum with white spot; metathorax with large, coarse punctures..... 14. simplicipes, Walsh. 
Scutellum black.

Clypeus entirely black

15. rubripes, n. sp.

Clypeus more or less rufous; posterior femora broadly black at apex, their tibiæ and tarsi black

16. canadensis, n. sp.

Clypeus white; posterior tibiæ pale ferruginous, black only at apex

17. virginiensis, n. sp.

Abdomen black, segments margined at apex with white: form short, robust, abdomen broad 18. albomarginata, n. sp.

Abdomen black, more or less varied with rufous.

Apex of first and whole of second and third segments rufous.19. macra, n. sp.

Apical margin of second and third segments rufous....

20. borealis, n. sp.

Apex of first, second and third segments broarlly rufous. 21. rufofasciata,n.s.

Abdomen entirely ferruginous or honey-yellow.

Thorax black; abdomen ferruginous 22. coloradensis, n. sp.

Thorax and abdomen honey-yellow 23. Dakota, n. sp.

1. Glypta tuberculifrons, Walsh, MS.- $q .--B l a c k$, shining; palpi, tegulæ and short line or spot before, whitish; antennæ rufo-testaceous beneath, base, apex, and above blackish; wings hyaline, faintly yellowish; legs including coxæ yellowish-red; anterior coxæ, trochanters and base of four anterior tibiæ, pale yellowish; tip of intermediate tibiæ and of posterior femora, black; posterior femora ferruginous, their tibiæ white, with black band at tip and one near base ; four posterior tarsi black, more or less white at base; face with a median, smooth, rounded swelling; thorax and abdomen with small, close, distinct punctures, more sparse on pleura which is polished; metathorax with larger, rather sparse punctures and with well defined elevated lines, the flanks more or less rufous; abdomen broader than usual, the oblique lines deeply impressed ; first gegment with two distant longitudinal carinæ at base, becoming obsolete about the middle; venter fuscous, banded with yellowish; ovipositor about the length of abdomen. Length 6 lines.

$\hat{\delta}$.-Differs from $q$ only by having the face clothed with a rather dense, short, white pubescence; the flanks of the metathorax are black in the single specimen examined. Length 6 lines.

Hab.-Illinois. Readily distinguished by the black clypeus and mandibles and by the entire black bands on posterior tibiæ.

3. Glypta erratica, n. sp.- + .-Black, shining; clypeus, mandibles except tips, palpi, tegulæ, and line before, w'aitish ; antennæ brown-black, darker at base, apex and above; wings hyaline; legs, including coxæ, yellowish-red; trochanters whitish beneath, posterior pair blackish above; intermediate tarsi fuscous, pale at base of joints; base and apex of posterior femora blackish ; their tibiæ black, with a white stripe above not reaching the apex and interrupted by a black spot near base, the tarsi black, more or less white at base of joints; face with a median rounded swelling; thorax minutely and closely punctured; metathorax rounded, smooth, shining, obsoletely punctured, apex enclosed by a well-defined arcuate carina; abdomen finely and densely punctured, the oblique lines deeply impressed, first segment with two sharply defined, longitudinal carinæ at base, becoming obsolete on middle; venter piceous; ovipositor as long as abdomen. Length $4 \frac{1}{2}$ lines.

$\checkmark$.-More slender than $q$; the metathorax above has two more or less distinct oblique carinæ, and the anterior coxæ are whitish. Length 4 lines. 
Hab.-New York; Pennsylvania; Delaware; West Virginia. A common species.

4. Glypta inversa, n. sp.- $q$.-More slender and smoother than erratica; the posterior tibiæ white, with a black band at apex and one near base, connected above by a slender black line; abdomen narrower and less deeply and closely punctured than that of erratica; otherwise the same. Length $4 \frac{1}{2}$ lines.

\section{Hab.-Massachusetts.}

5. Glypta pulchripes, n. sp.- - .-Black, shining; clypeus, mandibles except tips, palpi, tegulæ and dot before, white; antennæ brown above, pale rufo-testaceous beneath, basal joint blackish ; wings hyaline, beautifully iridescent ; anterior coxæ, intermediate pair beneath, the trochanters, and most of four anterior legs, white ; four anterior femora toward apex and intermediate coxæ behind, yellowish; intermediate tibiæ biannulate with pale fuscous; posterior coxæ and femora bright orange-yellow, the latter narrowly black at base and apex, their tibiæ white, with two entire black bands, one near base and the other at apex, their tarsal joints annulated with black and white; on each side of pleura a small red spot; face slightly prominent medially; head and thorax closely and delicately punctured; metathorax rounded, truncate behind; abdomen shining, distinctly punctured except at base and apex, the oblique lines deeply impressed; venter white; ovipositor rather longer than abdomen. Length 3 lines.

Hab.-West Virginia. This may be the (Anomalon) divaricata of Say.

6. Glypta rufiscutellaris, Walsh, MS.- O.-Black, shining; elypeus and mandibles sometimes tinged with rufous; palpi pale; antennæ bright rufo-testaceous, brown above and at base and apex beneath, second joint beneath pale; tegulæ, a spot or line before, anterior coxæ, intermediate pair beneath, four anterior trochanters, second joint of posterior pair, and four anterior tibiæ except apex, whitish ; four anterior tarsi pale, with tips of joints yellowish ; posterior tibiæ white, with a black band at apex and a spot near base, connected beneath by a slender black line; posterior tarsi black, basal half of first three joints white ; remainder of legs yellowish-red; wings hyaline, iridescent; apex of scutellum, more or less, flanks of metathorax, and a longitudinal, slightly oblique mark or spot on each side of pleura, red; face with rather dense, short, white pubescence, and with a rather prominent, polished tubercle on the middle; thorax closely, delicately though distinctly punctured; metathorax rounded above, sparsely punctured, with two longitudinal, diverging carinæ on the disk, the apex truncate and bounded above by a well-defined, areuate carina, the sides having a patch of short, pale pubescence; abdomen closely and distinctly punctured, more sparse on basal segment, the oblique lines deeply impressed, sides and apex slightly pubescent; longitudinal carinæ on first segment very prominent at base, becoming obsolete before apex; venter more or less pale; ovipositor as long as the abdomen. Length $3 \frac{1}{2}-4 \frac{1}{2}$ lines.

The $\delta$ has the antennæ, except basal joint, entirely pale fulvous; the legs much paler than in $\mathcal{f}$, the median swelling of face more prominent, and the flanks of metathorax entirely black; abdomen narrower and more opaque than in $\$$; venter white. Length $3 \frac{1}{2}$ lines.

Hub.-Connecticut; New Jersey; Illinois. Only one $\delta$ specimen 
observed. Easily recognised by the rufous scutellum and black mouth.

7. Glypta animosa, n. sp. $-q-$ Resembles rufiscutellaris, but more robust, the anterior margin, only, of clypeus, spot on mandibles, tip of scape beneath and upper margin of prothorax, are white; scutellum convex and entirely red, as also is the pleura beneath and partly on the sides; the black bands on posterior tibiæ are entire and not connected beneath by a black line; abdomen more robust and more densely punctured; ovipositor longer than the entire body ; otherwise as in rufiscutellaris. Length 4 lines.

\section{Hab.-New York.}

8. Glypta vulgaris, n. sp.- $-\delta \uparrow .-D i f f e r s$ from rufiscutellaris as follows:Clypeus and mandibles, except tips, white; scutellum entirely, and pleura except narrow space beneath wings, red; abdomen more closely and minutely punctured; ail the coxæ yellowish-red, the posterior femora black at tips. Length $3-4$ lines.

Hab.-Eastern and Middle States. This is our commonest species and is readily distinguished by the red pleura and scutellum, and white mouth.

9. Glypta longiventris, Walsh, MS.- $\delta .-B l a c k$, somewhat shining; face, except prominent median swelling, clypeus, mandibles except tips, space between eyes and base of mandibles, palpi, scape beneath, tegulæ, and upper and lower margins of prothorax, white; antennæ reddish-brown, darker above; pleura, except space beneath wings, flanks of metathorax and most of legs, yellowish-red; pleura beneath tinged with yellowish; wings hyaline, iridescent; anterior coxæ, intermediate pair beneath, and all the trochanters, white; intermediate tibiæ obfuscated above the middle and at tip; posterior femora black at apex and slightly so at base; their tibiæ black, pale fuscous on the middle and with a narrow white annulus at base, their tarsi black, with base of joints narrowly pale; mesothorax sub-trilobate, delicately punctured, shining: metathorax rounded, with the carinæ obsolete, except the arcuate one enclosing the apex ; posterior legs longer and more slender than usual; abdomen long, slender, subcylindrical, densely and confluently punctured, the oblique lines deeply impressed. Length 4 lines.

\section{Hab.-Illinois. One specimen.}

10. Glypta militaris, n. sp. $-q .-$ Black shining, with a very short pale pubescence ; clypeus, mandibles, palpi, scutellum, post-seutellum, pleura except space beneath wings, flanks of metathorax, most of legs, first abdominal segment, except fuscous stains on the sides, and broad apical margin of second and third segments, sanguineous; tegulæ and dot before, whitish; wings hyaline, faintly dusky at apex ; anterior coxæ, four anterior trochanters, extreme apex of their femora, and anterior tibiæ in front, yellowish-white; tips of posterior femora black; their tibiæ white, with a black band at apex and a narrow one near base; their tarsi black, basal half of first three joints white; antennæ obscure ferruginous, darker above, scape black; face with a rather prominent, smooth swelling; thorax and abdomen closely and distinctly punctured; metathorax with well-defined, elevated lines; abdomen shining at apex, the oblique lines deeply impressed; first segment with two longitudinal carinæ 
very prominent at base but obsolete beyond the middle; venter whitish; ovipositor rather shorter than abdomen. Length 4 lines.

Hab.-Illinois. Readily known by the three red bands on abdomen.

11. Glypta monita, n. sp.-.+- Black; clypeus, mandibles, palpi, tegulæ, line before, anterior coxæ, all the trochanters, and apex of all the femora, white; antennæ black above, brown beneath, scape beneath reddish; wings hyaline, iridescent; metathorax, scutellum, pleura, flanks of metathorax, and most of legs, sanguineous; four posterior tibiæ white, with a black or fuscous band at apex and a narrow one near base, connected beneath by a slender black or fuscous line; their tarsi annulated with black and white; face with a prominent, smooth, median swelling; mesothorax feebly punctured; metathorax with tolerably well-defined elevated lines, the punctures distinct, the apex truncate, rugulose and bounded above by a very prominent, sharp, arcuate carina ; abdomen very densely punctured, opaque, the oblique lines deeply impressed, apex smooth and shining; first segment less densely punctured at base and shining, the longitudinal carinæ flattened and polished; venter white; ovipositor as long as abdomen. Length 3 lines.

Hab.-West Virginia. A very distinct species.

12. Glypta? parva, n. sp.- $q .-$ Small, slender; head large, black, polished; eyes large, ovate, prominent; palpi whitish; antennæ long, slender, fuscous, white at base beneath; prothorax piceous, lower margin whitish; mesothorax, scutellums and pleura honey-yellow; tegulæ and spot before, white; metathorax black, feebly sculptured, flanks rufous, polished; mesothorax trilobate, smooth and polished; wings hyaline, beautifully iridescent; the second or terminal submarginal cell acutely pointed within, the second recurrent nervure much rounded outwardly; legs long, slender, white; anterior pair tinged with pale yellowish; base of posterior coxæ above, base of their femora, a line on onter side, base and apex of their tibiæ, and their tarsi except basal half of first joint, fuscous; abdomen delicately punctured, rufo-fuscous, blackish at base of first segment, on middle of third, fourth and fifth segments and apex; the grooves on second, third and fourth segments deeply impressed, twice oblique or angulate laterally, so that they enclose a rhomboidal space on the middle of the segment; apical segments smooth and polished; venter whitish; ovipositor short, scarcely as long as the two basal segments of abdomen, acutely sub-lanceolate. Length 2 lines.

Hab.-Illinois. This is not a true Glypta, differing in the neuration of anterior wing and in the sculpturing of the abdomen.

13. Glypta scitula, n. sp.-Q.-Small, robust, black, shining; face entirely, clypeus, mandibles except tips, palpi, orbits broadly dilated posteriorly toward the mouth, apex of scape beneath, margins of prothorax broadly interrupted above in front, tegulæ, short line beneath, sides and apex of scutellum, and transverse spot on postscutellum, white; antennæ black above, pale testaceous beneath; mesothorax yellowish-red, with a large quadrate black spot on the middle of anterior half, reaching anterior margin, and an elongate blackish stain on each side over the tegulæ; the anterior lateral margin suddenly dilated anteriorly on each side of black spot, and two slender longitudinal stripes becoming obsolete beyond the middle, white; scutellum above, pleura, flanks 
of metathorax and also the apex enclosing a black spot, yellowish-red; wings hyaline, beautifully iridescent; four anterior coxæ; apical half of posterior pair, all the trochanters, apex of four anterior femora, and their tibiæ, white; remainder of four anterior femora pale-yellowish; posterior femora yellowishred; base of posterior coxæ, base and apex of their femora, apex of their tibiæ, spot above near base, and their tarsi except base, black; remainder of their tibiæ and basal half of first tarsal joint, white; abdomen broad, feebly punctured, black, shining, the oblique lines not deeply impressed; apical margin, dilated laterally, of all the segments, lateral margin of each segment, dilated into a spot at base, and a small round spot on the middle of the first four segments, all white; venter whitish; ovipositor about three-fourths the length of the abdomen. Length 3 lines.

Hab.-New Jersey. This is a lovely little species, with the colors remarkably bright and varied.

14. Glypta simplicipes, Walsh MS.- + .-Black; clypeus, mandibles except tips, palpi, tegulæ, line before and spot on scutellum, yellowish-white; antennæ brown-black, paler beneath except base; legs, including coxæ, reddish-yellow, posterior pair darker, their tibiæ except base and their tarsi more or less, blackish; wings hyaline, faintly dusky; surface of body densely punctured, confluently so on abdomen, and with a short, pale, glittering pile; face scarcely prominent medially: metathorax rounded, coarsely punctured, with distinct elevated lines; abdomen robust, broader than usual, the oblique lines very deeply impressed, making the basal corners of the segments very prominent; apical margin of fourth and remaining segments smooth and polished; venter whitish; ovipositor nearly as long as abdomen. Length 5 lines.

The $\hat{\delta}$ has the four anterior legs in front, and their coxæ and trochanters yellowish-white, and the pleura is sometimes more or less reddish, as is also the flanks of metathorax; in one specimen, probably immature, the entire body is varied with pale ferruginous. Length $4 \frac{1}{2}-5$ lines.

Mab.-Mass.; N. Y.; Illinois. This is one of our most common species, and is easily distinguished from all others having the posterior legs not annulated with black and white, by the broad abdomen, white mouth and spot on scutellum.

15. Glypta rubripes, n. sp.- + .-Deep black, shining, with a very short, pale, glittering pile; clypeus and mandibles nigro-piceous; palpi pale fuscous; legs, including coxæ, reddish-yellow ; posterior tibiæ, except base, and their tarsi, black; wings hyaline, faintly dusky; venter whitish; face minutely, not very densely punctured, with a median swelling; thorax densely and finely punctured; metatborax more coarsely punctured, with well defined elevated lines, apex subtruncate, bounded above by an arcuate carina; abdomen long, rather narrow, with fine, close, distinet punctures, the three apical segments smooth and polished, the oblique lines deeply impressed; basal segment with two distant longitudinal carinæ at base; ovipositor as long as the body. Length 5 lines.

$\delta$-More slender, less shining, the abdomen very densely punctured and opaque. Length $4 \frac{1}{2}$ lines.

Hab.-Canada. 
16. Glypta canadensis, n. sp.- $q .-$ Black, shining; head and thorax with a short, fine, pale pile; clypeus, mandibles, tegulæ and palpi, rufo-testaceous; antennæ yellowish-brown; legs, including coxæ, reddish-yellow ; posterior trochanters, apical fourth of their femora, their tibiæ, except narrow pale annulus at base, and their tarsi, black; wings hyaline, iridescent; head, thorax and abdomen elosely and finely punctured; face slightly prominent medially; pleura and metathorax sparsely punctured, polished, the latter rounded, with prominent elevated lines; abdomen not strongly punctured, the oblique lines feebly impressed, obsoletely so on fourth segment; apical segments scarcely sculptured; venter whitish; ovipositor as long as abdomen. Length $3 \frac{1}{2}$ lines.

Mab.-Ontario, Canada. Easily distinguished by the tips of posterior femora being broadly black, and by the feebly impressed oblique lines on abdomen.

17. Glypta virginiensis, n. sp.- $q .-$ Black, shining; clypeus, most of mandibles, palpi and tegulæ, whitish; antennæ reddish-brown, fuscous above; legs, including coxæ, reddish-yellow, two anterior pair paler in front; extreme tips of posterior femora, spot near base of their tibiæ, their apices, and their tarsi, except base of joints, blackish; wings hyaline, iridescent, faintly yellowish; face minutely punctured, longitudinally prominent medially; mesothorax, pleura and sides of metathorax with close, distinct punctures; metathorax above with seattered punctures, apex enclosed by a sharply defined arcuate carina; abdomen very densely punctured, the median triangular space on second, third and fourth segments, formed by the deeply impressed oblique lines, smooth and polished, with scattered punctures only on the sides and anterior corner; apical segments smooth and polished; first segment rugulose laterally, the disk minutely, longitudinally aciculate, the longitudinal carinæ very prominent at base, but obsolete at tip ; venter whitish ; ovipositor as long as abdomen. Length $3 \frac{1}{2}$ lines.

Hab.-West Virginia. Remarkable for the smooth and polished triangular spaces on the abdomen.

18. Glypta albomarginata, n. sp.- $q$.- Short, robust, black, shining, with a short pale pubescence; rather broad entire orbits, clypeus, mandibles, palpi, tegulæ, line before, line beneath, two lines on mesothorax, dilated anteriorly, lateral and apical margin of scutellum, line behind on postseutellum, narrow apical margin of all the segments of abdomen and lateral margins of first segment, white; antennæ brown at tips; wings hyaline, beautifully iridescent; flanks of metathorax, and legs, orange-yellow ; four anterior coxæ black, pale at tips; dot at apex of posterior coxæ, their trochanters, narrow annulus on apex of their femora, tips of their tibiæ, a space near their base, and their tarsi entirely, black; extreme tips of their femora and base of their tibiæ, whitish ; venter whitish; metathorax rounded, with distinct punetures; scutellum elevated at apex, flattened above; legs short, robust; abdomen short, broad, robust, the segments short and transverse, the oblique lines tolerably well impressed; ovipositor about as long as abdomen, yellowish, lanceolate at apex, sheaths black, with long pubescence, apex yellowish-red. Length 3 lines.

Hab.-Maine. This has the same form as $G$. scitula, described above.

TRANS. AMER. ENT. SOC.

SEPTEMBER, 1870. 
19. Glypta macra, n. sp.-.+- Elongate, slender, black, shining; clypeus, mandibles, palpi and tegulæ, yellow: antennæ brown, paler beneath; wings subhyaline; legs, including coxæ, sanguineous, apical third of posterior femora and their tibiæ and tarsi, black or blackish; apical third of first segment of abdomen, the whole of second, and the third, except some fuscous stains, sanguineous; face with a median smooth swelling; metathorax rounded, the elevated lines sharply defined on the sides and apex, obsolete on the disk; abdomen smooth and shining, scarcely punctured, the oblique lines deeply impressed; venter whitish; ovipositor as long as abdomen. Length $4 \frac{1}{4}$ lines.

\section{Hab.-Canada. A very distinct species.}

20. Glypta borealis, n. sp.- $\hat{\delta}$.-Slender, black, shining; clypeus rufous: palpi, tegulæ and dot before, yellowish; antennæ ferruginous, darker above, scape yellowish beneath; wings faintly dusky, iridescent; legs, including coxæ, reddish-yellow; anterior coxæ in front, and four anterior trochanters, yellowish, tips of posterior tibiæ and of their tarsi, fuscous; narrow apical margin of second and third abdominal segments, rufous; face with a prominent median swelling; thorax densely and minutely punctured; metathorax more coarsely punctured, the apex enclosed by a sharply defined arcuate carina; abdomen densely punctured, apex smooth and shining, with a glittering pubescence; first segment sharply bicarinate on basal half, oblique lines deeply impressed: venter whitish. Length 4 lines.

\section{Hab.-Canada.}

21. Glypta rufofasciata, n. sp.-- .--Slender, black, subopaque; clypeus, mandibles, palpi and tegulæ, yellowish; antennæ black above, reddish-brown beneath, scape entirely black; wings hyaline, iridescent, nervures pale brown, stigma luteous; legs, including coxæ, reddish-yellow, anterior pair paler, apex of posterior femora, tips of their tibiæ, and their tarsi, more or less paler at base of joints, black; their tibiæ with a pale annulus at base, beneath which there is a fuscous band; apical third of first segment of abdomen, and apical half of second and third segments, bright rufous; metathorax with well defined elevated lines; abdomen densely punctured, apex smooth and polished, the oblique lines deeply impressed, first segment bicarinate on basal half; venter white. Length 4 lines.

\section{Hab.-Illinois. A beautiful species.}

22. Glypta coloradensis, n. sp.- $-\hat{-}$.--Elongate, narrow; head, thorax and two apical segments of abdomen, black; clypeus, mandibles except tips, palpi, tegulæ, four anterior coxæ and trochanters, and venter, pale lemon-yellow'; antennæ blackish above, pale testaceous beneath; wings hyaline, iridescent; posterior knees, tips of their tibiæ and most of their tarsi, blackish ; remainder of legs and abdomen above, except apex, ferruginous; oblique lines of abdomen deeply impressed. Length 5 lines.

$$
\text { Hab.-Colorado. }
$$

23. Glypta Dakota, n. sp.- + .-Pale ferruginous or honey-yellow, shining; head black; clypeus, mandibles, palpi, tegulæ and dot before, whitish; antennæ brown, darker above, scape beneath ferruginous; wings faintly dusizy, stigma luteous; base of posterior tibiæ whitish, their tips and tarsi obfuscated; abdomen rather broader than usual, finely punctured, the oblique lines deeply impressed; venter whitish; ovipositor nearly as long as abdomen, sheaths black. Length 4 lines. 
The $\delta$ has the face and space beneath eyes, ferruginous; otherwise like the ․ Length $3 \frac{1}{4}$ lines.

Hab.-Dakota.

SCHIZOPYGA, Grav.

Schizopyga frigida, n. sp.- - .-Black; mandibles, palpi, scape beneath and teguiæ, whitish; antennæ pale luteous beneath, fuscous above; face slightly raised and flattened, opaque, front excavated, smooth and polished, as also is the occiput, cheeks and thorax; wings hyaline, iridescent; legs short, robust, honey-yellow; four anterior coxæ and trochanters pale yellow; tips of intermediate tibiæ and of their tarsi, tips of posterior femora, their tibiæ, except base and broad white annulus about the middle, and their tarsi, except base, black; all the femora swollen; abdomen entirely black, somewhat-shining, minutely sculptured, the segments with lateral swellings most prominent on basal segments.

Hab.-Hudson's Bay Territory.

ARENETRA, Holmgren.

This genus is easily distinguished from Lampronota, by the head (especially,) and thorax being clothed with a dense, rather long, pubescence. The species may be separated as follows:-

Head and thorax clothed with black pubescence............... canadensis, Cress.

Head and thorax clothed with whitish pubescence.

Tegulæ black.

Posterior femora black....

2. nigrita, Walsh.

Posterior femora ferruginous ......................................... rufipes, n. sp.

Tegulæ yellowish-white........................................ ventralis, n. sp.

2. Arenetra nigrita, Walsh, MS.-.- Black, head and thorax opaque, abdomen except base shining; head, thorax and femora beneath with whitish pubescence, most dense on face and cheeks; head and thorax coarsely and rather closely punctured; wings tinged with fuscous, nervures and stigma black; anterior femora reddish-brown within, all the tibiæ and tarsi more or less fuscous, tarsi paler; abdomen shining, impunctured ; first segment transversely depressed before apex and minutely, longitudinally aciculated, the base deeply excavated; venter black; ovipositor about half as long as abdomen. Length $5-5 \frac{1}{2}$ lines.

The $\delta$ has the pubescence longer and much more dense; the wings clearer and all the knees, tibiæ and tarsi yellow or reddish-yellow; the first segment of abdomen much narrower, minutely, transversely rugulose, with a short tubercle on each side between middle and base; narrow lateral and apical margins of the second and following segments often more or less pale. Length $4 \frac{1}{2}-5$ lines.

Hab.-Canada; Massachusetts. Closely allied to canadensis, from which it is at once distinguished by the pubesence being whitish and not black.

3. Arenetra rufipes, n. sp.- $q$.-Differs from nigrita as follows:-The knees, tibiæ and tarsi, and also the posterior femora, except base, are ferruginous; the basal segment of abdomen is minutely rugulose, but not aciculated before apex as in nigrita; and the third and following segments have a very narrow yel- 
low apical margin; the ovipositor is as long as the abdomen. Length 5 lines. Hab.-Maine. In the single specimen before me, the second segment of abdomen is deeply and symmetrically emarginate on each side, which however may be a deformity.

4. Arenetra ventralis, n. sp.- $\hat{\delta}$.-Differs from nigrita as follows:-More robust; tegula yellowish-white; first abdominal segment broader, with subobsolete lateral tubercles; anterior half of venter yellowish. Length $5 \frac{1}{2}$ lines.

Hab.-New York; Pennsylvania.

CYLLOCERIA, Schiödte.

This genus is easily recognized by the $\hat{\delta}$ antennæ having the fifth and sixth joints erose, the former at apex and the latter at base. The anterior wing has no areolet.

Cylloceria occidentalis, n. sp.-.+- Black, shining; palpi yellowish; antennæ varies from reddish-brown to piceous; tegulæ white; wings faintly dusky, iridescent; legs, including coxæ, reddish-yellow ; posterior-tibiæ and tarsi black; mesothorax prominently trilobate; metathorax opaque, minutely rugulose, with pale pubescence, and with two approximate, discal, longitudinal carinæ; the three or four basal segments of abdomen densely rugulose, coarsely so on first segment, smooth and shining at apex; apical segments smooth and polished, and the posterior margin of the segments sometimes more or less reddish; venter whitish at base; ovipositor as long as abdomen. Length $3 \frac{1}{2}-5$ lines.

§.-More slender, and polished, with only the first segment of abdomen rugose, and which segment has a prominent tubercle on each side before middle. Length $3 \frac{1}{2}-4$ lines.

Mab.-Conn., Penn., West Va., Illinois.

Abdomen black.

LAMPRONOTA, Curtis.

Posterior coxæ red.

Pleura with a yellow or reddish mark on each side before middle coxa; scutellum more or less white on each side.

Large; areolet small, petiolated.

Abdomen coarsely punctured .......................... occidentalis, n. sp.

Abdomen minutely punctured ......................... scutellaris, n. sp.

Small ; areolet larger, not petiolated ........................ 3. pleuralis, n. sp.

Pleura entirely white; scutellum with a white spot on each side....

4. pulchella, n. sp.

Pleura and scutellum entirely black.

Abdomen smooth and shining....

5. lævigata, n. sp.

Abdomen punctured.

Lateral margin of mesothorax, before tegulæ, more or less yellow.

Posterior femora broadly black at tips .................... jocosa, n. sp.

Posterior femora not black at tips.

Medium ; abdominal segments entirely black........7. insita, n. sp.

Small; apical margin of second and third abdominal segments narrowly yellowish....

8. parva, n. sp.

Mesothorax black, immaculate.... 9. punctata, n. sp. 
Posterior coxæ entirely black.

Medium; posterior legs black except broad white annulus at base of their tibiæ; face and tegulæ white....................10. tegularis, n. sp.

Medium; posterior legs black, their femora red; face and tegulæ black

11. rufipes, Cress.

Small ; posterior legs, except coxæ and tarsi red 12. macra, n. sp. Abdomen red or yellow and black.

Base and apex of abdomen black.

Legs pale yellow, posterior femora and tarsi black; scutellum more or less yellow....

13. varia, n. sp.

Legs red; scutellum black 14. frigida, Cress.

Base only of abdomen black.

Legs entirely black.

15. americana, n. sp.

Only the femora red...

16. montana, Cress.

Legs entirely red; mesothorax reddish

17. exigua, n. sp.

A pex only of abidomen black

18. agilis, n. sp.

Abdomen entirely red; thorax black.

Scutellum black

19. exilis, n. sp.

Scutellum more or less yellow....

Body entirely ferruginous.

Abdomen opaque, densely punctured.... 20. rubrica, n. sp.

Abdomen smooth and polished...

21. brunnea, Cress.

1. Lampronota occidentalis, n. sp.- $\uparrow .-$ Black, opaque, densely punctured; clypeus, mandibles except tips, anterior orbits above antennæ, tegulæ, two spots beneath, broad line on each side of mesothorax before wings, dilated anteriorly, and two spots on scutellum, white; an elongate mark on each side of pleura before middle coxa, and the lower margin of flanks of metathorax, rufous; sides of pleura and flanks of metathorax polished; wings hyaline, areolet small, petiolated; legs ferruginous; anterior coxæ, four trochanters, extreme tips of their femora and base of all the tibiæ, pale yellowish; tips of posterior femora, more or less, the tibiæ except base, and their tarsi, blackish; abdomen densely and strongly punctured, apex smooth and shining; ovipositor as long as body. Length $6-6 \frac{1}{2}$ lines.

Hab.-Pennsylvania. This is our largest species.

2. Lampronota scutellaris, n. sp.- . - - Black, subopaque, very densely and minutely punctured; clypeus, mandibles, palpi, anterior orbits, tegulæ, broad line before, short line beneath, two lines on scutellum, and elongate mark on each side of pleura before middle coxa, yellowish-white; disk of scutellum sometimes ferruginous; wings faintly tinged with yellowish-fuscous; areolet small, petiolated; metathorax coarsely rugose centrally; pleura and flanks of metathorax more or less reddish beneath ; legs ferruginous, four anterior coxæ, trochanters and knees, more or less yellowish; apex of posterior femora, of their tibiæ and their tarsi, fuscous or black; extreme base of posterior tibiæ pale; abdomen somewhat shining, with a short, fine, whitish pile at apex, very minutely sculptured; ovipositor as long as abdomen. Length $5 \frac{1}{2}-6$ lines.

Hab._-West Virginia; Illinois.

3. Lampronota pleuralis, n. sp.-Q.-Differs from occidentalis by being much smaller, by the mark on each side of pleura being yellow or white, instead of 
rufous, and by the areolet of anterior wing being larger and scarcely at all petiolated. Length 4 lines.

$\delta$.-Slender, black, opaque ; face entirely, extending beneath eyes, clypeus, mandibles, palpi, anterior orbits interrupted before summit, apex of first joint of antennæ beneath, spot on second joint, a cuneiform spot or line on each side of mesothorax, tegulæ, two marks beneath, occasionally a spot on each side of scutellum, lower margin of prothorax, a large, irregular mark on each side of pleura before middle coxa, sometimes meeting beneath, and four anterior coxæ and trochanters, yellowish-white; metathorax densely rugose; wings faintly yellowish-fuscous, areolet larger than usual, subtriangular, not petiolated; legs pale ferruginous, posterior tibiæ and tarsi more or less fuscous; abdomen narrow, slender, shining at apex, apical margin of second and third segments sometimes reddish; venter yellowish. Length $3-4$ lines.

Mab.-Canada; Mass., N. Y., Del., W. Va., Pa., Ill. A common species.

4. Lampronota pulchella, n. sp.- - .-Black, somewhat shining, finely and closely punctured; face entirely, extending beneath eyes, clypeus, mandibles, palpi, anterior orbits, scape beneath, tegulæ, mark beneath, hooked line in front, two spots at base of scutellum, and pleura, except broad upper margin, white; antennæ as long as body, brown-black above, pale rufo-testaceous beneath; spot on flanks of metathorax rufous; wings hyaline, irideseent, areolet small, petiolated; four anterior legs white, intermediate femora yellowish; posterior legs honey-yellow, trochanters and tibiæ whitish, apex of tibiæ and tarsi black; abdomen long and slender; venter whitish. Length 5 lines.

Hab.-New Jersey. A very pretty species, easily recognized by the white pleura.

5. Lampronota lævigata, n. sp.-Black, shining; head and thorax closely and finely punctured; abdomen smooth and shining; clypeus, mandibles, palpi, tegulæ and legs, yellowish-red; posterior tibiæ except base, and tarsi; blackish; wings hyaline, areolet small, petiolated; antennæ brown-black; metathorax densely rugulose; abdomen convex, subsessile; ovipostor longer than body. Length 5 lines.

Hab.-Canada.

6. Lampronota? jocosa, n. sp.- $\}$.-Black; sides of face (narrowed beneath and leaving a large triangular black mark on middle) extending beneath eyes and acutely notched beneath insertion of each antenna, dot at summit of each eye, clypeus, spot on mandibles, spot on scape beneath, tegulæ, spot beneath, and broad hooked line in front on each side of mesothorax, white; wings hyaline, iridescent, areolet subtriangular, not petiolated; antennæ brown-black; legs ferruginous, apical third of posterior femora, their tibiæ and tarsi, black; abdomen depressed, subpetiolate, gradually broader to apex. Length $3 \frac{1}{2}$ lines.

\section{Hab.-Illinois. Not a true Lampronota.}

†. Lampronota insita, n. sp.- $q$.-Black, rather shining, closely and finely punctured; clypeus, mandibles and anterior orbits above antennæ, roseate or flesh-color; palpi whitish; antennæ nearly as long as body, slender ; tegulæ, spot beneath, and a broad, somewhat hooked line before, on each side of mesothorax, white; wings hyaline, areolet triangular, not petiolated; legs honey- 
yellow; anterior coxæ, four anterior trochanters and base of posterior tibiæ, white; posterior tibiæ except base and their tarsi, black; three basal segments of abdomen closely and strongly punctured, apreal segments smooth and shining; venter whitish. Length $4 \frac{1}{2}$ lines.

\section{Hab.-New Jersey.}

8. Lampronota parva,n. sp.- $q$.-Small, black, opaque; clypeus, mandibles, palpi, dot at summit of each eye, tegulæ, narrow line before, on each side of mesothorax (sometimes obsolete or wanting), anterior coxæ behind, their trochanters and spot on intermediate coxæ beneath, white; wings hyaline, iridescent, areolet opaque, sub-petiolated; legs ferruginous, tips of posterior tibiæ and their tarsi more or less, fuscous; abdomen shorter and broader than usual, depressed, densely and finely punctured, shining at apex, apical margin of second and third segments narrowly yellowish, sometimes obsoletely so; venter yellowish, ovipositor as long as abdomen. Length $2 \frac{1}{2}-3$ lines.

Hab.-Canada; Del., West Va.

9. Lampronota punctulata, n. sp.-.+- Small, black, opaque, densely and finely punctured; clypeus, mandibles and palpi pale reddish; dot at summit of each eye, and tegulæ, white; wings hyaline, sometimes faintly dusky ; areolet subtriangular, not petiolated; legs pale ferruginous, posterior tibiæ and tarsi more or less fuscous; metathorax densely rugulose; abdomen long, narrow, densely and minutely punctured, terminal margin of the segments and the two or three apical segments smooth and polished; apical margin of second and third segments sometimes narrowly yellowish; venter whitish; ovipositor as long as abdomen. Length $3-4$ lines.

Mab.-Canada; Mass., Conn., West Va.

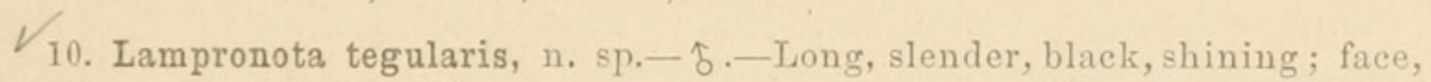
clypeus, mandibles, palpi, scape beneath and tegulæ, white; antennæ brown beneath; except base; pleura smooth and polished; metathorax coarsely punctured; wings hyaline, iridescent, faintly dusky at tips, areolet minute, petiolated; four anterior legs, including coxæ, and basal half of posterior tibiæ, white; four anterior femora and apical half of their tibiæ, honey-yellow, remainder of posterior legs black; abdomen long, narrow, with close distinct punctures, the two or three apical segments smooth and shining. Length $5 \frac{1}{2}-$ 6 lines.

Hab.-Canada; Penn., Del., Ills. A very distinct and well marked species.

12. Lampronota macra, n. sp.- $\delta$.-Small, slender, black, opaque; narrow anterior orbits below antennæ, space beneath eyes, spots at summit of each eye, clypeus, mandibles, palpi, tegulæ, mark beneath and line before on each side of mesothorax, white ; wings hyaline, iridescent, areolet triangular, petiolated; legs honey-yellow; anterior coxæentirely and intermediate pair, except black spot at base beneath and above, white; posterior coxæ and their trochanters above, black, posterior tarsi fuscous; abdomen with incisures between second, third and fourth segments reddish. Length $3 \frac{1}{2}$ lines.

Hab.-Delaware. This has, at first sight, much the appearance of pleuralis $\delta$, but is quite distinct. 
13. Lampronota varia, n. sp.- - -Black, shining; face, clypeus, mandibles, palpi, space beneath eyes, anterior orbits, occasionally interrupted, sometimes spot behind eyes, scape benefth and spot above, upper and lower margins of prothorax, two longitudinal lines on disk of mesothorax, sometimes obsolete or wanting, broad lateral margin confluent anteriorly with discal lines, tegulæ, one or two spot beneath, more or less of scutellum, irregular mark on each side of pleura before middle coxa, sometimes wanting, four anterior legs including coxæ, posterior coxæ, except more or less of base beneath, their trochanters, knees and tibiæ exeept tips, pale yellow, posterior tarsi fuscous; antennæ as long as body, brown beneath; wings yellowish-hyaline, areolet small, petiolated; abdomen sub-cylindrical, shining, first segment. except apex, and the fifth and following segments, black; remainder yellow varied with ferruginous, or vice versa, sometimes varied with dusky, sometimes yellowish-ferruginous margined at apex with whitish; venter yellowish. Length 6 lines.

Var.- $\hat{\delta}$.-Face with a central black line; antennæ entirely black; venter and pleura immaculate; scutellum with two narrow white lines; posterior coxæ entirely black; apex of first segment of abdomen, and the second, third and fourth segments entirely, uniformly ferruginous. Length $5 \frac{3}{4}$ lines.

Hab.-Canada ; Mass., Conn., West Va. A common and very variable species, easily distinguished from all others by the coloration of the legs.

15. Lampronota americana, n. sp.-.+- Black; clypeus and anterior legs tinged with rufous; wings fusco-hyaline, areolet slightly petiolated; abdomen smooth and shining, rufous, first segment except apex black; ovipositor as long as body. Length 6 lines.

Hab.-Canada; West Va., Ills. This species mimics Cryptus americanus in color.

1\%. Lampronota exigua, n.sp.- + .-Small; head and thorax black; elypeus, mandibles, palpi and antennæ, except base above, pale testaceous, the latter fuscous above; mesothorax ferruginous, blackish centrally and behind; tegulæ yellowish, a ferruginous spot beneath; wings hyaline, beautifully iridescent, nervures and stigma pale honey-yellow, areolet 5-angular, not petiolated; legs pale ferruginous, posterior coxæ with a fuscous spot; abdomen ferruginous, the first segment except apex black; the ovipositor as long as body. Length $2 \frac{1}{2}$ lines.

\section{Hab.-West Virginia.}

18. Lampronota agilis, n.sp.- $\uparrow$.-Slender, black; apical margin of elypeus dull yellowish; mandibles and palpi brown ; antennæ brown-black, flagellum sometimes pale at base; thorax entirely black, sides of metathorax finely pubescent; wings byaline, faintly dusky, iridescent, nervures and stigma black, areolet very minute, petiolated; legs black, the two anterior pairs varied with testaceous, four posterior coxæ and base of posterior femora more or less, bright ferruginous; abdomen subclavate, shining, ferruginous, the fourth and following segments and oceasionally the apical margin of the third segment, black; ovipositor short, about one-third the length of abdomen. Length $3 \frac{1}{2}-4$ lines.

$$
\text { Hab.-New York; Pennsylvania. }
$$


19. Lampronota exilis, n. sp.- + -Long, slender, black; apical margin of clypeus, mandibles, palpi and tegulæ, dull testaceous; upper anterior orbits pale yellowish; flanks and apex of metathorax and lower margin of pleura more or less rufous; wings subhyaline, tinged with yellowish fuscous, areolet small, petiolated ; legs ferruginous, posterior tibiæ and tarsi sometimes more or less fuscous, trochanters black, apex of the two anterior pairs yellowish; abdomen entirely ferruginous, sometimes the apex is more or less fuscous, ovipositor as long as body. Length $4 \frac{1}{2}$ lines.

$\delta$.-Face more or less, clypeus, mandibles, palpi and scape beneath, yellowish ferruginous; upper margin of prothorax with a reddish spot; legs entirely ferruginous; base of first abdominal segment sometimes black. Length $4 \frac{1}{2}$ lines.

\section{Mab.-Canada ; Mass., Conn.}

20. Lampronota rubrica, n. sp.- - .-Head and antennæ black; most of elypeus, mandibles, palpi, and upper anterior orbits, pale yellow ; pro- and mesothorax and pleura black; two dots in front of mesothorax, sometimes wanting, tegulæ and scutellum, lemon-yellow; metathorax and spot on each side of pleura, ferruginous; basal margin of metathorax more or less black; wings hyaline or subhyaline, areolet more or less petiolated ; legs ferruginous, trochanters more or less black, posterior tibiæ and tarsi tinged with fuscous; abdomen entirely ferruginous; ovipositor as long as body. Length $4 \frac{1}{2}$ lines.

Var. \&.-Metathorax black, ferruginous only at sides and apex; scutellum with two yellow spots; mesothorax immaculate. Length $4 \frac{1}{2}$ lines.

\section{Hab.-Mass., Conn, West Va.}

22. Lampronota coloradensis, n. sp.- $q$.-Large, yellowish-ferruginous; anterior orbits dilated beneath eyes, clypeus, mandibles, anterior lateral margin of mesothorax, and tegulæ, lemon-vellow ; antennæ black, scape ferruginous; wings hyaline, faintly yellowish, areolet small, petiolated ; metathorax dull ferruginous, rugulose, with a deep central groove; pleura and flank, of metathorax smooth and polished; anterior legs in front tinged with yellowish; abdomen smooth and polished; venter pale yellow, spotted with fuscous; ovipositor as long as abdomen. Length $5 \frac{1}{2}-6$ lines.

Hab.-Colorado.

MENISCUS, Schiödte.

4. Meniscus elegans, n. sp.- $q$--Black; orbits, dilated beneatb eyes, spot on middle of face, sometimes divided into two and sometimes confluent with orbital line, clypeus, mandibles, palpi, apex of scape beneath, upper and lower margins of prothorax, two spots on front of mesothorax, a spoton the disk, tegulre, a spot beneath, a spot on each side of pleura anteriorly, another in front of each middle coxa, scutellum except base, line on postscutellum, subtriangular spot at apex of metathorax, a dot on each flank, four anterior legs, apex of their coxæ, apex of posterior trochanters, knees, and base of their coxæ, lemonyellow; abdomen rufo-ferruginous, first and second dorsal segments black, base and apex of first segment and apex of second, yellow ; wings hyaline, apex fuliginous, areolet subrhomboidal, with a long petiole; head and thorax with a short fine pubescence; thorax with large punctures, more coarse and somewhat rugose on metathorax; ovipositor as long as abdomen. Length $4-5 \frac{1}{2}$ lines. 
The $\hat{\delta}$ has the face entirely, scape beneath and seutellum entirely, lemonyellow; the two spots on front of mesothorax are much larger than in $q$, while the marks on pleura become confluent, forming an irregular, rather oblique line; antennæ slender, rufo-testaceous beneath; apex of abdomen dusky. Length $4 \frac{1}{2}$ lines.

\section{Hab.-N. Y., Md., W. Va., Missouri.}

2. Meniscus mirabilis, n. sp.- $q .-$ Black, shining; clypeus, mandibles, paIpi, space beneath eyes, short narrow orbital line on each side of antennæ, spot at summit of each eye, tegulæ, line before, and a cuneiform spot on each side of mesothorax, yellowish-ferruginous ; wings hyaline, iridescent, areolet wanting; legs honey-yellow, coxæ and trochanters lemon-yellow, four posterior coxæ within and a line on outside, and all the trochanters behind except tips, black; extreme base of posterior femora, a narrow band before apex, apex of their tibiæ and their tarsi more or less, black or fuscous; abdomen black, smooth and shining, apical margin of second and following segments narrowly whitish; venter yellowish; ovipositor as long as body. Length 4 lines.

Hab.-Massachusetts. This looks very much like a Lampronota, but the tarsal claws are pectinated and the areolet wanting.

\section{PHYTODIETUS, Grav.}

1. Phytodietus vulgaris, n. sp. $-q .-$ Black, head and thorax subopaque, abdomen smooth and polished; mandibles except tips, palpi, spot at summit of each eye, second joint of antennæ, tegulæ, line in front on each side of mesothorax, apex of scutellum, two dots at base, spot on postscutellum and a transverse line before apex of metathorax, sometimes interrupted or reduced to a lateral dot, white; pleura beneath and flanks of metathorax sometimes more or less rufous or ferruginous; wings hyaline, areolet obliquely triangular, petiolated; antennæ brown towards apex; legs pale bright ferruginous, most of anterior coxæ, their trochanters, apex of middle trochanters, apical half of posterior pair, all the knees, and four anterior tibiæ and tarsi white, base of their femora, broad band before apex, their tibiæ, except a more or less distinct pale line about middle, sometimes forming a broad white band, and their tarsi, sometimes more or less pale at base, black; abdomen subsessile, apical margin of all the segments narrowly whitish, interrupted laterally; ovipositor nearly as long as abdomen. Length $3-5$ lines.

Var. .-Angular mark on middle of face, spot beneath eyes, upper anterior orbits, mark on disk of mesothorax and transverse subapical line on metathorax dilated medially, white; clypeus piceous ; antennæ brown ; pleura whitish beneath; flanks of metathorax ferruginous; posterior tibiæ white, the apex and narrow annulus before base, black; base of posterior tarsi white. Length $4 \frac{1}{2}$ lines. (Canada).

ऊ.-Face entirely, clypeus, mouth, scape beneath, lateral and apical margins of scutellum, and four anterior legs, all white; antennæ as long as body ; otherwise marked as in $q$. Length $4 \frac{1}{2}$ lines.

Hab.-Canada; Mass., Conn., Penn., Del., Ills. A common and variable species.

2. Phytodietus distinctus, n. sp.-Differs from vulgaris as follows:-Clypeus whitish, mandibles white only before apex; anterior orbits white; metathorax has a central white spot and one on each side, forming a semicircle; posterior 
legs ferruginous, with only the apex of tibiæ and their tarsi dusky; abdomen subpetiolated; venter white, banded with black. Length 5 lines.

Var. \&.-Face, mesothorax, pleura and metathorax black, immaculate. Length $4 \frac{1}{2}$ lines.

Hab.-Mass., Del. Quite distinct from vulgaris by the subpetiolated abdomen and differently colored posterior legs.

\section{XORIDES, Grav.}

Xorides borealis, n. sp.- $q .-$ Black; narrow anterior orbits, palpi, tegulæ and lower margin of prothorax white; wings hyaline; anterior legs whitish, yellowish behind, four posterior coxæ and trochanters, and intermediate femora, pale ferruginous; intermediate tibiæ and tarsi dusky, posterior femora, tibiæ and tarsi black; base of their tibiæ narrowly white; incisures of abdominal segments more or less whitish; venter banded with white; ovipositor as long as abdomen. Length 5 lines.

Hab.-Hudson's Bay Territory.

EUXORIDES, n. gen.

Closely resembles Xorides, from which it is at once distinguished by the anterior wing having a triangular, subpetiolated areolet; the head is more transverse, being less broad behind the eyes; the face wider beneath; and the posterior legs proportionally shorter and more robust.

Euxorides americanus, n. sp.- $q .-$ Black, opaque; palpi, scape beneath, lower margin of prothorax, tegulæ and spot before, white; clypeus and mandibles rufo-piceous; metathorax finely rugulose, channelled centrally and with short glittering pile laterally; wings hyaline, iridescent; anterior coxæ and legs white, their femora yellowish behind; four posterior legs, including coxæ, honey-yellow, tips of intermediate coxæ, trochanters, knees, tibiæ, apical half of posterior trochanters and their knees, whitish; intermediate tarsi, base of posterior trochanters, their femora at base and before apex, their tibiæexcept base and their tarsi, black; abdomen convex, somewhat shining, incisures of the segments whitish; venter more or less whitish; ovipositor shorter than abdomen. Jength $4 \frac{1}{2}$ lines.

Hab.-Conn, Penn., Texas.

Abdomen entirely black.

XYLONOMUS, Grav.

Prothorax above with a prominent lateral tubercle.

Wings with a fuscous band...

1. australis, n. sp.

Wings entirely hyaline....

2. humeralis, Say.

Prothorax simple.

Legs entirely black.

3. cincticornis, Cress.

Legs black, base of tibiæ and of tarsi white....

4. stigmapterus, Say

Four anterior legs and posterior coxæ ferruginous..... ..5. frigidus, $n . \mathrm{sp}$. Abdomen with lateral white spots... 6. albopictus, n. sp.

1. Xylonomus australis, n. sp.- - .-Large, black, opaque; head piceous or rufo-piceous, face densely rugulose, vertex and cheeks smooth, shining, with scattered punctures; mouth black; antennælong, slender, black, with a broad white annulus beyond the middle; thorax rough and uneven, tinged with 
brown beneath where the surface is smooth, rather sparsely punctured and shining; prothorax above with a robust acute tubercle on each side; mesothorax excavated medially, coarsely punctured and somewhat transversely striated; metathorax densely rugose, the flanks coarsely punctured, the apex with a short lateral spine; wings subhyaline, apex dusky, a broad ill-defined fuliginous band on anterior pair beneath stigma, which is black with a white spot at base; legs black, polished, the trochanters more or less, the knees, the anterior legs in front and all the tarsi rufo-testaceous; abdomen densely rather finely rugose, smoother at apex; ovipositor as long as body. Length $9 \frac{1}{2}$ lines.

Hab.-Louisiana, Texas. Sometimes the four anterior legs are entirely reddish-brown.

5. Xylonomus frigidus, n. sp.- + .-Small, robust, black, shining; mouth piceous; wings hyaline; metathorax opaque, with prominent elevated lines; legs, including coxæ, pale ferruginous, anterior pair pale in front; posterior femora, their tibiæ exeept base, and their tarsi black; abdomen shorter and broader than usual, subsessile, densely minutely sculptured, base rugulose, apex shining; ovipositor as long as body. Length 5 lines.

Hab.-Hudson's Bay Territory. This has much the form of an Odontomerus.

6. Xylonomus albopictus, n. sp.- - .-Black, shining, face except a median brown line, anterior orbits, clypeus, broad posterior orbits, scape beneath, upper and lower margin of prothorax, short line beneath tegulæ, apex of scutellum, spot or postscutellum, band on apex of metathorax, and a spot on each apical corner of all the abdominal segments, white ; base of mandibles, palpi and margin around clypeus, dull rufous; clypeus concave; thorax depressed above; metathorax short and broad, with well defined elevated lines, base smooth and polished, central rhomboidal space transversely aciculate, apex with a small lateral tubercle; wings hyaline, iridescent; legs short and rather robust, two anterior pairs honey-yellow ; the trochanters and four anterior knees whitish; four anterior tibia with a dusky spot before base, apex of their tarsi also dusky ; posterior legs, except trochanters and base of their tibiæ, black ; abdomen much depressed, almost flat, subpetiolate, subclavate, second and third segments with an arcuated lateral groove, making the middle more or less prominent; apex incurved, shining. Length $5 \frac{1}{2}$ lines.

Hub.-New York.

ODONTOMERUS, Grav.

Body and legs entirely black ...................................... æ.

Body black, legs yellowish ferruginous ..............................2. mellipes, Say.

Body and posterior legs black

3. vicinus, n. sp.

Head and thorax black; abdomen and legs ferruginous.

Large ; coxæ and trochanters ferruginous

4. bicolor, n. sp.

Small ; coxæ and trochanters black.... abdominalis, Cress.

3. Odontomerus vicinus, n. sp.- $-\delta$.-Differs from mellipes $\delta$ only by the posterior legs, including their coxæ, being black, except base of their femora, and apex of their trochanters, which are honey-yellow, or concolorous with the four anterior leg. Length 5 lines. 
Hal.-Massachusetts. The tubereles at apex of metathorax are not so prominent as in mellipes, and the abdomen less shining.

4. Odontomerus bicolor, n. sp.- $q$.-Black, polished, head and thorax with scattered punctures; metathorax with sparse pubescence, and with two approximate median carinæ, sides coarsely punctured; wings tinged with fuliginous; legs including coxæ and abdomen except extreme base of first segment, ferruginous; ovipositor much longer than the body. Length $7 \frac{1}{1}$ lines.

Hab.-Pennsylvania.

\section{IIST. \\ COLEOCENTRUS, Grav.}

Pettitii, Cress., Canadian Entomologist, i, p. 35, ㅇ.

AROTES, Grav.

formosus, Cress., Can. Ent. i, p. 34; Trans. Am. Ent. Soc. ii, p. 260, $\delta$ 오.

vicinus, Cress., Trans. Am. Ent. Soc. ii, p. 260, $\delta$.

venustus, Cress., Trans. Am. Ent. Soc. ii, p. 260, $\delta$ ․

amœnus, Cress., Can. Ent. i, p. 34 ; Trans. Am. Ent. Soc. ii, p. 260 , $\hat{\delta} q$.

decorus, Say., Bost. Jour. Nat. Hist. i, 248. Cress., Trans. Am. Ent. Soe. ii, p. $260, \delta$.

ACENITES, Grav.

rupinsulensis, Walsk. Cress., Trans. Am. Ent. S̈oc. iii, p. 143, $\uparrow$.

RHYSSA, Grav.

persuasoria, Linn., \&c. Cress., Proc. Ent. Soc. Phil. iv, p. 278, $\hat{f} f$

albomaculata. Cress., Proc. Ent. Soc. Phil. iii, p. 31 , $\{$.

canadensis, Cress., Can. Ent. i, p. 35, .

THALESSA, Holmgr.

Nortoni, Cress., Proc. Ent. Soc. Phil. iii, p. 317, $\{$.

lunator, Fabr., Ent. Syst.ii, p. 162, ( $\delta q)$.

atrata, Fabr., Ent. Syst. ii, p. 179. Brulle, Hym. tab. 40, fig. 1, \&.

laevigata, Brullé, Hym. p. 78 ; tab. 40 fig. $2, \delta$.

nitida, Cress., Proe. Ent. Soc. Phil. iii, p. 319, $\hat{\delta}$.

EPHIALTES, Grav.

rex, Kriechb., Stett. Ent. Zeit. xv, p. 155, ( $q$ ).

occidentalis, Cress., Proc. Ent. Soc. Phil. iv, p. 269, $q$.

tuberculatus, Fowrer. Grav. Ich. Eur. iii, p. 228, ( $q$ ).

perlongus, Cress., Trans. Am. Ent. Soc. iii, p. 143, $\delta$.

macer, Cress., Can. Ent i, p. 35, of $ᄋ$.

albipes, Cress., Trans. Am. Ent. Soc. iii, p. 143, .

irritator, Fabr., Ent. Syst. ii, p. 164. ( $\delta$ \&.)

EPIMECIS, Brullé.

Wiltii, Cress., Trans. Am. Ent. Soc. iii, p. 143, $q$.

PERITHOUS, Holmgr.

pleuralis, Cress., Can. Ent. i, p. 36, .

THERONIA,, IIolmgr.

melanocephala, Brullé, Hym. p. 99, ( $\delta q$ ).

fulvescens, Cress., Proc. Ent. Soc. Phil. iv, p. 268, ( $\delta \uparrow)$. 
PIMPLA, Fabr.

maura, Cress., Trans. Am. Ent. Sac. iii, p. 145, $q$. atrocoxalis, Cress., Trans. Am. Ent. Soc. iii, p. 145, $q$. pedalis, Cress., Proc. Ent. Soc. Phil. iv, p. 268, ( $\hat{\delta}$ \& $)$. texana, Cress., Trans. Am. Ent. Soc. iii, p. 145, $ᄋ$. tenuicornis, Cress., Proc. Ent. Soc. Phil. iv, p. 267. ( $\delta \oint$ ). annulipes, Brullé, Hymen. p. 102, ( $\delta$ ). aquilonia, Cress., Trans. Am. Ent. Soc. iii, p. 145, $\hat{\delta}$. Ontario, Cress., Trans. Am. Ent. Soc. iii, p. 146, $\widehat{\delta}$. picticornis, Cress., Trans. Am. Ent. Soc. iii, p. 146, $\hat{\delta}$. novita, Cress., Trans. Am. Ent. Soc. iii, p. 146, $q$. indagatrix, Walsh. Cress., Trans. Am. Ent. Soc. iii, 146, $\delta$. annulicornis. Walsh. Cress., Trans. Am. Ent. Soc. iii, p. 147, $\{q$. pleurivinctus, Say, Bost. Jour. Nat. Hist. i, p. 232. conquisitor, Say., Bost. Jour. Nat. Hist. i, p. 232, ( $\delta q$ ). incompleta, Cress., Trans. Am. Ent. Soc, iii, p. 147, ․ inquisitor, Sxy, Contrib. Mael. Lyc. i, p. 71, ( $\delta$ 익). alboricta, Cress., Trans. Am. Em. Soc. iii, p. 147, $\hat{\alpha}$. rufopestus, Cress., Trans. Am. Ent. Soc. iii, p. 148, $q$. scriptifrons, Welsh. Cress., Trans. Am. Ent. Soc. iii, p. 148, 9. pterelas, Say, Contrib. Macl. Lyc. i, 71, ( $\delta q)$. notanda, Cress., Trans. Am. Ent. Soc. iii, p. 148, $\delta q$. rufovariata, Cress., Trans. Am. Ent. Soc. iii, p. 149, $q$.

\section{POLYSPHINCTA, Grav.}

texana, Cress., Trans. Am. Ent. Soe. iii, p. 149, $q$. Burgessii, Cress., Trans. Am. Ent. Soc. iii, p. 149, $\delta$. limata, Cress., Trans. Am. Ent. Soc. iii, p 150, $q$.

\section{CLISTOPYGA, Grav.}

annulipes, Cress., Trans. Am. Ent. Soc. iii, p. 150, $q$.

GLYPTA, Grav.

tuberculifrons, Walsh. Cress., Trans. Am. Ent. Soc. iii, p. 152, $\delta q$. varipes, Cress., Proc. Ent. Soc. Phil. iv, p. 267, + . erratica, Ciess., Trans. Am. Ent. Soc. iii, p. 152, $\delta$ ㅇ. inversa, Cress., Trans. Am. Ent. Soc. iii, p. 153, $q$. pulchripes, Cress., Trans. Am. Ent. Soc. iii, p. 153, $q$. rufiscutellaris, Walsh. Cress., Trans. Am. Ent. Soc. iii, p. 153, $q$. animosa. Ciess., Trans. Am. Ent. Soc. iii, p. 154, $q$. vulgaris, Cress., Trans. Am. Ent. Soc. iii, p. 154, $\delta$. longiventris, Wilsh. Cress., Trans. Am. Ent. Soc. iii, p. 154, $\delta$. militaris, Cress., Trans. Am. Ent. Soc. iii, p 154, $q$. monita, Cress., Trans. Am. Ent. Soc. iii, p. 155, $q$. ? parva, Cress., Trans. Am. Ent. Soc. iii, p. 155, $\subsetneq$. scitula, Cress., Trans. Am. Ent. Soc. iii, p. 155, $q$. simplicipes, Wulsh. Cress., Trans. Am. Ent Soc. iii, p. 156, $\delta$. rubripes, Cress., Trans. Am. Ent. Soc. iii, p. 156, $\delta$ \&. canadensis, Cress., Trans. Am. Ent. Soc. iii,p. 157, $q$, virginiensis, Cress., Trans. Am. Ent. Soc, iii, p. 157, $\{$. albomarginata, Cress., Trans. Am. Ent. Soc. iii, p. 157, $q$. macra, Cress., Trans. Am. Ent. Soc. iii, p. 158, $q$. 
borealis, Cress., Trans. Am. Ent. Soc. iii, p. 158, $\hat{\delta}$. rufofasciata, Cress, Trans. Am. Ent. Soc. iii, p. 158, $\hat{\delta}$. coloradensis, Cress., Trans. Am. Ent. Soc. iii, p. 158, $\widehat{\delta}$. Dakota, Cress., Trans. Am. Ent. Soc. iii, p. 158, $\hat{q}$.

SCHIZOPYGA, Grav.

frigida, Cress., Trans. Am. Ent. Soc. iii, p. 159, $q$.

ARENETRA, Holmgr.

canadensis, Cress., Can. Ent. i, p. 26, $\delta$.

nigrita, Walsh. Cress., Trans. Am. Ent. Soc. iii, p. 159, $\hat{\delta} \nmid$.

rufipes, Cress., Trans. Am. Ent. Soc. iii, p. 159, ㅇ․

ventralis, Cress., Trans. Am. Ent. Soc. iii, p. 150, $\widehat{\delta}$.

CYLLOCERIA, Schiödte.

occidentalis, Cress., Trans. Am. Ent. Soc. iii, p. 160, $\delta$ ․

LAMPRONOTA, Curtis.

oozidentılis, Cress, Trans. Am. Ent. Soc. iii, p. 161, ㅇ. scutellaris, Cress., Trans. Am. Ent. Soc, iii, p. 161, pleuralis, Cress., Trans. Am. Ent. Soc. iii, p. 161, $\delta$ ?. pulchella, Cress., Trans. Am, Ent. Soc. iii, p. 162, $\widehat{\jmath}$. lævigata, Cress., Trans. Am. Ent. Soc, iii, p. 162, $q$. jocosa, Cress., Trans. Am. Ent. Soc. iii, p. 162, $\delta$. insita, Cress., Trans. Am. Ent. Soc. iii, p. 162, ․ parva, Cress., Trans. Am. Ent. Soc. iii, p. 163, $q$. punctulata, Cress., Trans. Am. Ent. Soc. iii, p. 163, $q$. tegularis, Cress., Trans. Am. Ent. Soc, iii, p. 163, $\delta$. rufipes, Cress., Can. Ent. i, p. 36, ․

macra, Cress., Trans. Am. Ent. Soc. iii, p. 16.3, $\widehat{\delta}$. varia, Cress., Trans. Am. Ent. Soc. iii, p. 164, $\delta$. frigida, Cress., Can. Ent. i, p. 36, ( $\delta$ ). americana, Cress., Trans. Am. Ent. Soc. iii, p. 164, $q$. montana, Cress., Proe. Ent. Soc. Phil. iv, p. 267, ㅇ. exigua, Cress., Trarss. Am. Ent. Soc. iii, p. 164, $\nmid$. agilis, Cress., Trans. Am. Ent. Soc. iii, p. 164, exilis, Cress., Trans. Am. Ent. Soc. iii, 165, $\delta$. rubrica, Cress., Trans. Am. Ent. Soc. iii, p. 165, $q$. brunnea, Cress., Can. Ent. i, p. 37, ㅇ.

coloradensis, Cress., Trans. Am. Ent. Soc. iii, p. 165, $q$.

MENISCUS, Sehiödte.

elegans, Cress., Trans. Am. Ent. Soe. iii, p. 165, $\delta$ ㅇ․

Bethunei, Cress., Can. Ent. i, p. 105, $q$.

mirabilis, Cress., Trans. Am. Ent. Soc. iii, p. 166, $q$.

PHYTODIETUS, Grav.

vulgaris, Cress., Trans. Am. Ent. Soc. iii, p. 166, $\hat{\delta} q$. distinctus, Cress., Trans. Am. Ent Soc. iii, p. 166, $q$. pleuralis, Cress., Proc. Ent. Soc. Phil. iv, p. 266, $\delta$.

XORIDES, Grav.

vittifrons, Cress., Can. Ent. i, p. 37 , $(\delta q)$. borealis, Cress., Trans. Am. Ent. Soc. iii, p. 167, . 
EUXORIDES, Cresson.

americanus, Cress., Trans. Am. Ent. Soc. iii, p. 167, $\&$.

XYLONOMUS, Grav.

australis, Cress., Trans. Am. Ent. Soc. iii, p. 167, $q$. humeralis, Say, Contrib. Macl. Lyc. i, p. 74, $q$. cincticornis, Cress., Proc. Ent. Soc. Phil. iv, p. 288, 오. stigmapterus, Say, Long's 2d Exped. ii, p. 325 , ( $\delta$ ). frigidus, Cress., Trans. Am. Ent. Soc. iii, p. 168, + . albopictus, Cress., Trans. Am. Ent. Soe. iii, p. 168, $\delta$.

ECHTHRUS, Grav.

niger, Cress., Can. Ent. i, p. $37, \delta \subsetneq$.

abdominalis, Cress., Can. Ent. i, p. $37, \delta q$.

ODONTOMERUS, Grav.

æthiops, Cress., Proc. Ent. Soc. Phil. iv, p. 289, $\delta$ 오.

mellipes, Say, Contrib. Macl. Lyc. i, p. 74; Bost. Jour. ii, p. 242, $\delta$ ㅇ․

vicinus, Cress., Trans. Am. Ent. Soc. iii, p. 168, $\delta$.

bicolor, Cress., Trans. Am. Ent. Soc. iii, p. 169,

abdominalis, Cress., Proc. Ent. Soc. Phil. iv, p. 289, ㅇ․"

DESIDERATA.

Acænitus melleus, Say, Bost. Jour. ii, p. 249, $q$,

Pimpla humida, Say, Bost. Jour. ii, p. 224, $\{.-$ This evidently belongs to the genus Rhyssa.

Pimpla rufipes, Brullé, Hymen. p. 102, $\hat{f} q .-$ This is probably South American while his annulipes is a common North American species.

Anomalon divaricatus, Say, Bost. Jour. ii, p, 244.-This is a species of Glypta and possibly identical with G. pulchripes described above. 


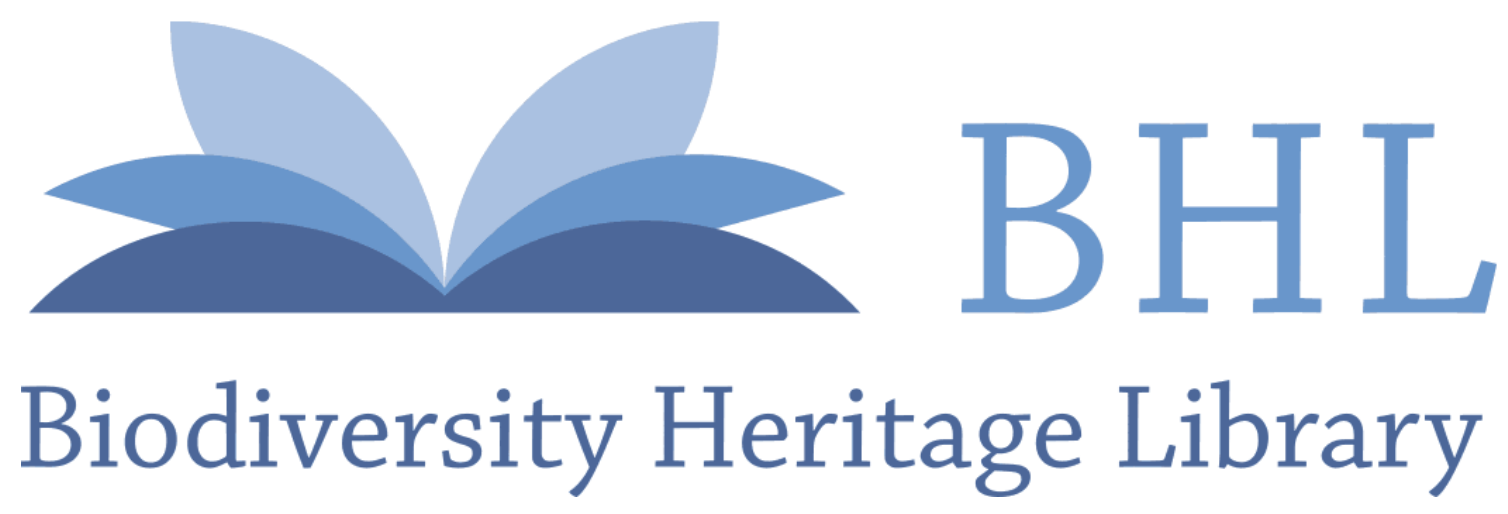

Cresson, E. T. 1870. "Descriptions of new species belonging to the subfamily Pimplariae found in America north of Mexico." Transactions of the American Entomological Society 3, 143-172.

View This Item Online: https://www.biodiversitylibrary.org/item/32422

Permalink: https://www.biodiversitylibrary.org/partpdf/21856

\section{Holding Institution}

Smithsonian Libraries

\section{Sponsored by}

Smithsonian

\section{Copyright \& Reuse}

Copyright Status: NOT_IN_COPYRIGHT

This document was created from content at the Biodiversity Heritage Library, the world's largest open access digital library for biodiversity literature and archives. Visit BHL at https://www.biodiversitylibrary.org. 